\title{
Macroeconomic Impact on Stock Market Returns and Volatility: Evidence from Sri Lanka
}

\section{Antonette Fernando*}

Department of Financial Intelligence, Central Bank of Sri Lanka, Colombo, Sri Lanka

\begin{abstract}
The paper examines the relationship between stock market returns and selected macroeconomic variables and examine the impact of macroeconomic uncertainty on stock market volatility in Sri Lankan stock market. Interest rate, inflation, money supply and exchange rate are selected as a set of exogenous variables to represent the macroeconomic factors that influence the stock market, returns and volatility. The sample includes monthly stock market index and macroeconomics data from 1998 to 2016 covering 228 data points. In achieving research objectives, Vector Error Correction Model (VECM) and Exponential Generalized Autoregressive Conditional Heteroskedasticity $($ EGARCH) models are specified and estimated.
\end{abstract}

The results of Johansen Juselius co-integration test indicate a long run relationship between macroeconomic variables and stock returns. Particularly, the results of co-integration test suggest that there is a significant negative effect of Treasury bill Rate (TBR) and Exchange Rate (EXR) on stock returns while significant positive long run effect of Money Supply (MSI)/Inflation (INF) on stock returns. The Error Correction Term (ECM) in the VECM model indicates only 4.1 percent of the long run shock adjusted in the short run period and supports the argument of weak form of market efficiency in the Colombo Stock Exchange (CSE), Sri Lanka. Further, the results of the EGARCH model evidence the presence of asymmetric volatility in the monthly stock returns which suggest that the bad news in the CSE has larger effect on the volatility of the stock market than the good news. Similarly, the model establishes that interest rate and money supply create macroeconomic risk to the volatility of the stock market returns in Sri Lankan context. Accordingly, this paper, as a whole, conclusively establishes that the stock returns and market volatility are dependent on macroeconomic variables.

These findings hold managerial and policy implication at least to the Sri Lankan policy makers, market regulators, investors and market analysts. The test results suggest the information inefficiency in the Colombo stock market. Further, Investors in the market should look at the systematic risks revealed by the money supply and short term interest rates when structuring portfolios and diversification strategies. Policymakers may need to take these macroeconomic variables into account when formulating economic and financial policies.

Keywords: Stock returns; Market volatility; Stock market efficiency; EGARCH; VECM; Colombo stock exchange

\section{Introduction}

\section{Background of the study}

Assets prices are commonly believed to be in reaction to macroeconomic environment changes [1]. Hence, the movement of stock market index is an important aspect in the dynamics of economic fundamentals, while being a leading macroeconomic indicator. According to the financial theory, price of a stock reflects the investor's expectation about future micro and macroeconomic prospects [2]. The stock market is a focal point in the modern day economy as it assists in financial intermediation between lenders and borrowers. Stock market as a prominent economic institution plays the primary role in efficient capital formation and effective allocation of resources. A well-structured stock market is essential for domestic and international capital mobility and an inefficient capital market limits economic development. Thus, overall economic growth is a product of a well-developed and efficient stock market.

Markowitz [3] portfolio theory, analyses how to combine financial assets to maximize return while minimizing the total risk that comprises of both unsystematic and systematic risk. Unlike in unsystematic risk, systematic risk cannot be minimized through diversification of portfolio. In line with the risk minimization and diversification strategies of the portfolio theory, contemporary financial theory focuses on macroeconomic variables as a source of systematic risk. Arbitrage Pricing Theory (APT) introduced by Ross [4] characterizes systematic risk as a combination of multiple factor and accordingly the APT measures the risk premium using various factors that influence the asset returns. However, neither the type of factors nor the number of factors determines the asset prices, which are specifically defined in APT [5]. Hence, these theoretical gaps together with the importance to understand the trends in capital markets and the asset pricing models motivate researchers to carry out empirical studies in different stock markets in different time periods.

Further, the relationships between stock market and macroeconomic condition were communicated and introduced by Fama and Malkiel [6] through the theory of Efficient Market Hypothesis $(\mathrm{EMH})$. For last several decades this has been at the centre of debate in financial literature. In accordance with $\mathrm{EMH}$, the price of a financial asset needs to reflect relevant information about that particular asset. Especially, the quick and instantaneous adjustment in assets prices to

*Corresponding author: Antonette Fernando, Department of Financial Intelligence, Central Bank of Sri Lanka, Colombo, Sri Lanka, Tel:+0452514453, E-mail: cfernando@deakin.edu.au

Received October 31, 2018; Accepted November 21, 2018; Published November 28,2018

Citation: Fernando A (2018) Macroeconomic Impact on Stock Market Returns and Volatility: Evidence from Sri Lanka. Bus Eco J 9: 379. doi: 10.4172/2151. 6219.1000379

Copyright: (c) 2018 Fernando A. This is an open-access article distributed under the terms of the Creative Commons Attribution License, which permits unrestricted use, distribution, and reproduction in any medium, provided the original author and source are credited. 
arrival at new information is known as an effective capital market. If $\mathrm{EMH}$ holds, investors cannot expect to achieve excess profits from their investment strategies. From an economic perspective, the efficient market is important as it applies to a well-functioning stock market when allocating scarce resource among economic agents. Nevertheless, this is not always true for emerging stock markets context. The pioneer empirical study conducted by Chen et al. [1] provided attestation to the idea that there is a relationship between stock prices and macroeconomic variables. This study illustrates how economic factors influence the firms; ability to generate cash flow, future dividend pay outs and the firm's cost of capital. Subsequently, Fama [7], Fama and French [8], Asprem [9], Bilson et al. [10], Bulmash and Trivoli [11], Chen et al. [12], Gjerde and Saetterm [13], Wasserfallen [14] empirically note that, change in macroeconomic condition systematically respond to changes in stock prices. These studies confirm that the movement of share returns is highly sensitive to the changes in the fundamental economic parameters.

Moving from first to second phase, at first Veronesi [15] formulates a theoretical model that establishes a hypothetical relationship between macroeconomic uncertainty and stock market volatility. Volatility of stock market refers to the amount of risk or uncertainty pertaining to the capacity of market index [16]. In other words, higher volatility indicates when security value or stock market index fluctuates dramatically through a large range of value over a specific period of time. Stock market volatility was empirically well-established through the pioneering work of Mandelbrot [17] and Black [18]. Veronesi [15] suggest that investors are highly sensitive to the information about economic uncertainty and in turn it increases the volatility of asset price. Stock market volatility study on the US market by Schwert [19] states that stock market volatility is not closely related to measures of macroeconomic volatility and he concludes it as volatility puzzle. Similarly Chan et al. [20] noted that macroeconomic variables do a poor job in explaining the stock market volatility. Accordingly, second phase of stock market study that establishes empirical relationship between the stock returns and macroeconomic factors have proven to be much more challenging. In finance, the volatility of stock prices is typically calculated by the standard deviation or variance. Highly volatile share market means the stock market index or prices of stocks have remarkable swings over a given period, i.e., within a day, week, month, and year [16]. Based on this argument, volatility of stock index is considered as the risk involved with stock market and uncertainty in investment decisions [21]. Understanding the dynamics of stock market behaviour is important as excess volatility may affect the performance of asset market [21].

\section{Significance of the study}

The existing literature provides mix results on the relationship between stock returns and macroeconomic variables. This could be due to different variables and sample periods, different economic conditions and dissimilar method that which are utilized. Moreover, the empirical evidence on the stock returns predictability of developing market is relatively low despite it being extensively available for the developed markets. Therefore, examining the nature of relationship between macroeconomic variables and share market returns in Colombo Stock Market assists the entire interested group to decide operational, managerial, sustainable growth decision efficiently. This study expects to deliver valuable insight for investors, portfolio management and policymakers.

As supported by the efficient market hypothesis diversification benefit, a portfolio is less correlated to publicly available information and stock market returns. However, when weak forms of efficient market exist, market participants get an opportunity to use macroeconomic news to gain excess returns. In that sense, this study is important to all market participants including investors, portfolio and fund managers. Further, national policy formulation process should not demote the capital market of the country which limits trading and capital creation in the economy. Furthermore, regulators can formulate different policies and decisions for ensuring and creating smooth trading and investment atmosphere in the stock market based on their experience and knowledge on the behaviour of stock market.

When it comes to Sri Lankan stock market, only handful numbers of studies have been conducted [22-24] to ascertain the macroeconomic impact on stock return and no empirical study has been published on impact of macroeconomic condition on the volatility of stock market. Further, as no empirical study has been conducted based on Colombo stock market after 2011, existing literature would be relatively old and outdated to the current financial market condition. Therefore there is a need to carryout study on macroeconomic variables and stock market returns. To this end, this study is aimed at filling the gap in the existing literature.

The rest of the report is organized as follows. Chapter two focuses on the review of existing literature including theoretical background to establish the relationship between macroeconomic variables and stock market behaviour. Chapter three is devoted to research design where it presents the econometric models and data used in this study. Chapter four analyses the results obtained through the models employed. Chapter five allocated to the discussion managerial implications followed by the conclusion.

\section{Literature Review}

\section{Theoretical background}

The finance and economics literature offers theories that explain the relationship between the stock market and macroeconomic variables. The APT developed by Ross [4] is most influential multifactor asset pricing model in contrast to the single factor CAPM (Capital Assets Pricing Model). In the CAPM, the expected returns of a security is a linearly related to the returns of market portfolio while the APT assume that the expected returns of financial assets is a liner function of its expected returns plus other macroeconomic factors that do not have firm control. The portfolio theory highlights the unsystematic risk can be minimized by well diversified portfolio. Unlike in the CAPM that systematic risk is associated with a signal factor, the APT identifies multifactor systematic risk that affect to all firms in the same degree [12]. Accordingly, the APT measures the risk premium using more than one common factor. This argument is in consistence with the EMH hypothesis introduced by Fama and Malkiel [6] who states that factors affecting stock prices need to be justified by market fundamentals.

APT model holds with several underline assumptions [25]; financial asset markets are perfectly competitive, no restriction imposed on short selling no arbitrage opportunities exist in the financial market, investors should possess homogeneous expectation about returns of assets that generate randomly based on multifactor model and investors face concave and monotonically increasing utility function. Several researchers [1,25-28] have conducted prominent empirically studies on APT in different economic contexts. However, none of these specifies what macroeconomic factors that needs to be incorporated in to the asset pricing model [29]. Therefore this theoretical gap has become a research question of subsequent empirical research in various stock markets in different time periods. 


\section{Stock market returns and macroeconomic variables}

Over the last two decades the relationship between macroeconomic variables and the stock returns has been unsolved research question among both economic and financial scholars. The literature were focused on both developed and emerging market context and extended literature reveal strong relationship between macroeconomics variables and stock returns under different econometric models. The first empirical study of this relationship [1] has investigated a set of economic state variables as systematic influences on stock market returns and has examined their influence on asset pricing. In this influential paper, they justified his study from the viewpoint of efficient-market theory and arbitrage pricing theory [4] which demonstrates prices of financial assets should base on their exposures to the state variables which describe the economy. They explained that the macroeconomic variables, such as expected and unexpected inflation, industrial production (IP), the spread between long and short interest rates, and the spread between high and low-grade bonds, systematically influence stock returns via future dividends and discount rates. In this research study they used simple arguments to choose a set of economic state variables that were candidates as sources systematic risk of assets. Most of such economic variables were noted to be significant in explaining expected stock returns. Based on such empirical study, they conclude that stock returns are exposed to systematic economic news, that they are priced in accordance with their exposures, and that the news can be measured as innovations in state variables whose identification can be accomplished through simple and intuitive financial theory. Subsequent to this land mark study the efficient market hypothesis has been empirically examined. Vast majority of these studies concluded the stock returns can be predictable and the stock markets are indeed weakly efficient.

Among various econometric models, Choi [30], Brooks et al. [31], Chen et al. [12], Gan et al. [32], Ratanapakorn and Sharma [33] have used co-integration analysis to identify the relationship between macroeconomic variables and stock returns in developed countries like US, UK, Japan Canada, and Australia. These studies applied Engle and Granger [34] or Johansen and Juselius [35] approach in Vector Auto Regression (VAR) framework to assess the co-integration relationship.

\section{Stock market volatility and macroeconomic variables}

Financial and economic time series are depended on their past values, prior information and exhibits non constant variance. In econometric language time series data found to be autoregressive, conditional and heteroskedastic respectively [36]. Also, as suggest by Francq and Zakoian [37], volatility in prices of financial asset are found to be time varying and positive serial correlation which is also called as volatility clustering. Any financial time series have three main characteristics that are volatility clustering leverage effect and leptokurtosis. Over the last decades, attention of the academics and researchers have placed on modelling volatility of financial time series. Variance or standard deviation of time series is often used as the measurement of risk involve with the variables. Hence, stock returns being the time series data set carries all these properties.

Both ARCH and GARCH models successfully capture the first two properties of volatility i.e., volatility clustering and leptokurtosis but not asymmetric shocks to the volatility. Before moving to the asymmetric effect, volatility clustering is known as a scenario where large fluctuation in the price of the stock tend to follow by the similar large changes irrespective of such fluctuations are favourable or unfavourable to investors [37]. In the event of volatility clustering the squared series required to be highly auto correlated. Moving on to the asymmetric term, asymmetric reaction of conditional variance as response to negative or positive shocks in error is known as asymmetric term or leverage effect. This leverage effect can be highlighted when an unexpected fall in stock price due to negative shock increases predictable volatility in the stock prices, than when an unexpected increase in stock price due to positive shocks. Hence the results derive from symmetric ARCH or GARCH models will be spurious. This defect of GARCH model in capturing leverage effect was discovered by several scholars [38-39]. Nelson [40] proposed Exponential GARCH (EGARCH) model to handle the symmetric distribution based on logarithmic expression of the conditional volatility. Thresholds ARCH (TARCH), Quadratic GARC (QGARCH) are other models subsequently developed to capture asymmetric property. Several researchers conduct their empirical study using EGARCH model to identify the volatility reaction of the stock market in relation to the macroeconomic shocks in developed market context [41-48]. However, studies on the effect of dynamics of stock market volatility to macroeconomic shocks on emerging markets such as Sri Lanka are limited. Hence, this study is use EGARCH model to capture the dynamic of Sri Lankan stock market and to identify how the macroeconomic shocks effect on the volatility of the same.

\section{Economic variables and stock return}

Interest rate and stock return: Interest rate is one of the most prominent economic factors that determine the behaviour of the investor in taking investment decisions. The effect of interest rate on stock returns has been empirically tested in literature. Campbell's [49] research work observes the relationship between term structure of interest rate and excess returns in US stock market. Fama and Schwert [50] support the negative relationship not only with current interest rate but also lag interest rate. Zhou [51] ascertains the interest rate impact on stock price using a regression analysis. His findings confirmed the long term interest rate impact on stock price while rejecting the hypothesis of one to one movement of expected stock returns with ex ante interest rate. Zhou [51] also proposes higher volatility in long term interest rate causes corresponding higher volatility in stock market index. Mukherjee and Naka [52] use simple dividend discount model in hypothesizing inverse relationship between stock price and interest rate. The change in the short term and long term government bond rate expected to influence the nominal risk free discount rate and in return the discount rate. Similarly, Chan et al. [53], Chen et al. [1], Beenstock and Chan [54] provide evidence on the relationship between stock returns and interest rate.

The relationship between inflation and stock price has been empirically tested extensively in existing literature. However, the dynamic relationship between stock price and inflation is a matter of debate as the empirical findings are mixed. The first empirical study by Jaffe et al., [55] using US data, establish inverse relationship between these two variables. As per the estimated results of this pioneering study stock returns were inversely related to anticipate inflation for the period 1953-1971 while returns were independent of past rate of inflation for the period 1975-1970. However, results suggest positive relationship between these variables over a longer period and this hold the fisher hypothesis. Fisher effect state that the interest rate should fully adsorb expected inflation movements to maintain equilibrium interest rate. As suggested by Fama and Schwert [50], in principle fisher hypothesis can be extended to any financial assets including stock. Similarly, Choudhry [56] discovered positive relationship between stock returns and inflation in four countries that perceived as higher inflation countries namely Chile, Argentina, Venezuela and Mexico. 
Nelson [57], Bodie [58], Firth [59] and Boudhouch and Richardson [60] subsequently conduct similar study and identify positive relationship between stock returns and expected and unexpected rate of inflation. Boudoukh and Richardson [60], Engsted and Tanggaard [61] also observe the positive relationship over long time horizons and their results support the fisher hypothesis with the wider time horizon as equity is a hedge against inflation in long run.

On the other hand, Fama [7] illustrates a negative relationship between inflation and stock returns on the basis of money demand and quantity theory of money. Fama and Schwert [50] study confirm inverse relationship between these two variables and conclude stocks not serve as a hedge against expected and unexpected inflation. The argument that stock market perform as a hedge against inflation implies higher inflation will increase the nominal stock index while keeping the real return unchanged. Hence no investor earns loss due to expected inflation and they are fully compensated. Negative impact of inflation on stock price can be justifiable if the expected inflation proportionately transmitted to the nominal interest rate. Increase in inflation likely to adapt tight monetary policy, which in turn increase the nominal interest rate. Higher nominal interest rate leads to higher discount rate in the stock valuation model, end up with lower stock price.

Money supply and stock return: Like inflation, there is no dispute on the theoretical link between stock prices and money supply. The relationship between money supply and stock prices has been found in financial and economic literature. The modern quantity theory of money presented by Friedman and Schwartz [62] explain that rise in money supply due to an exogenous shock result to alter the equilibrium money balance in an investor's portfolio. In simple terms, money compete with other financial assets included in a portfolio to secure it place and alter the composition and price of other assets in the portfolio. This increase in the money supply is expected to generate an excess supply of money balances while leading to an excess demand for other financial assets including stocks. Higher demand pressure coming from the market result in increases share price.

Further, monetary policy tightening would increase the real interest rate which in turn raises the discount rate thereby reducing stock value. Additionally it during the tight monetary policy demands higher risk premium to compensate for holding risky assets like stock. Bernanke and Kuttner [63] note that the stock price is a function of its holding period risk and monetary value. Accordingly, stock is an attractive investment when the monetary value is high given a perceived risk of holding it. At times of tight money supply, the economic activities will slow down. In that case the investors require relatively high risk premium to hold risky asset. An increasing risk premium leads stock unattractive to the investors and that will result in decrease in stock price. Homa and Jaffe [64], and Booth and Booth [65], confirm the theory that the expansionary monetary policy increases stock prices.

Moreover, another indirect relationship advocates relationship between changes in money supply and stock prices in favour of real activity. This view explains a positive money shocks has a positive impact on aggregate economy and thereby causes increase stock prices. In other words, higher economic activity ensures higher cash flows which expect to increase stock returns. Besides decreasing interest rate causes the discount rate to drop down which again push up the value of the stock. This view implies investor has avenue to earn excess profit by monitoring the behaviour of the money stock in the economy [66]. This finding clearly violates the EMH as past information can be make use in predicting stock prices.
Exchange rate and stock return: There are few theoretical approaches to explain the relationship between the exchange rate and the stock prices. Among these approaches the portfolio balance approached by Frankel [67] a good market approach by Dornbusch and Fisher [68] are two popular in illustrating the impact of exchange rate movements on the stock market. Dornbusch and Fisher [68] discuss the fluctuation in exchange rate and stock market behaviour using the trade account/current account. The theory emphasizes that the change in the exchange rate affects the competitiveness of local goods in the international market and thereby change the trade balance. In fact, the depreciation of the local currency makes domestic firms relatively more competitive and increase exports. Higher income from exports related companies lead to increase in share price. Similarly, at the time of currency appreciation, the converse is true and the share price of export related firms decrease. While this relationship seems straightforward it can be argued that this relationship depends on the degree of dependence on international trade to the domestic economy and the relative size of the import and the export companies listed in the particular stock market.

According to the portfolio balance theory of Frankel [67], there is a positive relationship between the exchange rates and stock prices. The basic of the argument depend on the compassion of the portfolio held by an investor. In general investors diversify their exposure to both domestic and foreign assets including different currencies. When there is a bloom in domestic stock market, it will attract more capital inflows from foreign markets and disposal of foreign asset leads to local currency to appreciate against foreign currency. Similarly at the time of bear market domestic currency tend to depreciate against foreign currency.

\section{Selection of variables}

Previous research in finance and economics e.g., reveals existence of relationship between macroeconomic factors and share price and share index [1,6,7,9,25,31,69,70-77]. According to these seminar research a wide range of factors explain returns and risk of stock index including money supply, exchange rates, interest rates, real activity, political risks, commodity price, oil prices, budget deficits, trade deficits, domestic consumption, unemployment rate, imports, real wage and regional share market indexes etc. Nevertheless, all factors are not equally important and relevant to every share market, every economy and every research period. Hence, in the light of the above considerations and balancing the theoretical propositions and prior evidence, four macroeconomic variables are selected for this study. These variables are interest rate, inflation rate, money supply and exchange rate. In a number of emerging market studies $[13,78,79]$ these variables are shown to explain the variation in stock returns.

The selection of these macroeconomics variables are based on several reasons. First the Treasury bill rates operate as the rate of return offered by the risk free assets. As stated by Kang et al. [75] investor's decision on shifting of funds between risky equity and risk free assets is extensively influenced by the movements in Treasury bill rates. High-treasury bill rates tend to encourage investors to purchase more government instruments. Hence, the Treasury bill tends to compete with shares for the resources of investors. This tends to reduce the demand for shares and causes an eventual reduction in share returns. Further, interest rate has an impact on the level of company profit and in turn influences the price of the stock that potential investor willing to pay to compensate the expected future cash flows. When the company finances its operation from the borrowed funds, reduction in interest rate leads to reduction in the firm cost of capital. This brings 
the intention to expand the business which will have positive effect on the expected return of the firm. Based on the above grounds, expected relationship between stock returns and treasury bill rates is negative.

As Ratnapakorn and Sharma [33] explain, the rise or fall in inflation reduces or increases the purchasing power of investor and consequently has an impact on the equity investment decision of local investor. In other words, higher inflation raise the cost of living and a shift of resources from the stock market instruments to consumables items can be expectable. This leads to a drop in the demand for shares which tends to cut down the volume of trading. Market capital which is calculated as the product of the share price and the outstanding shares may therefore fall as the demand for shares falls due to the substitution process. Hence, inflation is expected to have a negative impact on the market index and the performance of the exchange.

As explained by Mayasami et al. [79], broader money supply represent by M2b, measures the liquidity in the economy and market. Hence any change in the money supply should have an impact on the investment decision of the individual investor. An increase in $\mathrm{M} 2 \mathrm{~b}$ growth would indicate excess liquidity available for buying securities, resulting in higher demand for securities. Accordingly the money supply is expected to have a positive impact on the market index and the performance of the exchange.

Finally, movement in exchange rate depreciation/appreciation makes Sri Lankan equity comparatively cheaper /expensive to foreign investors and therefore fluctuation in exchange rate should have an impact on equity investment decision of foreign investors. The changes in the exchange rate affect the competitiveness of local goods in the international market and thereby change the trade balance. In fact, the depreciation of the local currency makes domestic firms relatively competitive and increase exports. Higher income of export oriented companies lead to increase the share price. Similarly, at the time of currency appreciation the converse is true and the share price of export related firms drops down. Since Sri Lanka is relatively import oriented country the depreciation of the inflation rate expected to has negative impact of the stock returns.

However, these variables represent only a subset of economic variables that used in prior studies. Yet, these are the only variables with sufficient observation available to the researcher, for the time period considered under this study. For instance, even though there the study intents to include variable such as GDP to represent the real activity of economy, the non-availability of the data on monthly basis, prevent researcher from bringing that variable into the analysis. Despite the fact that, Industrial Production (IP) has been used as a closer proxy to the GDP by researchers in previous studies, that has not been taken into the model as Industrial Production ignored the non-factory industrial sector, agricultural and service sector of the economy. In Sri Lanka IP represent around 8-10 percent of the GDP. Hence IP is not sound approximation of the GDP. Nevertheless, selecting variables in research studies is usually subject to criticism on the grounds of subjectivity. Fama [7] has argued that such criticism is an unavoidable problem associated with this area of research. Hence, this study bases its selection of variables on theoretical propositions and existing evidence in the literature.

\section{Research motivation}

Based on the literature review, it is clear that the stock market is highly sensitive to changes in investors' sentiments about future prospects of individual companies, industry and the economy as a whole. These sentiments are formed by macro and micro prospects that are made either rationally or adaptively based on economic ground rules, together with many subjective factors. The existing literature presents a number of finance theories that connect between stock market behaviour and economic activities. The EMH suggest that stock prices and stock market index are fully rational and fully incorporate all relevant information; as such past information is not useful in forecasting future stock prices. Hence, only new information is used to predict future stock prices and stock market behaviour [6]. On the other hand, a number of asset pricing theories such as APT and the Present Value Model (PVM), which in turn the dynamic link between the stock market and economic activities [80].

Unlike in the past, last couple of decades exhibited remarkable growth in market activities and relative importance of stock markets in developing countries including Sri Lanka. With the protracted internal conflict coming to an end in May 2009, the CSE has recorded a remarkable growth of over 300 percent. The end of the national conflict together with expectations of sustainable economic growth uplifted the sentiment of investors, corporate community and the general public at large. Consequently, Bloomberg recognized the CSE as one of the outperforming markets during the years 2010, 2011. Again it was recognized as one of the best performing stock markets in the world in 2014 by appreciating over 22 percent [81]. During the post war era, the net asset value of unit trust has tremendously appreciated to around 1020 percent [82]. In addition to higher returns, stock market liberalizations and economic growth in developing countries have attracted attention of multinational equity mangers. Financial market trends towards globalization and international diversified portfolio strategies provide the environment in which emerging stock markets could thrive against well- established giants. Similarly, in recent times, global investors and researchers have turned their attention to emerging financial markets, especially those of South-East Asia. Share markets in these countries have provided attractive investments opportunities to foreign investors and have become investment icons in the global financial market.

Nevertheless, while Sri Lanka's capital market remains underdeveloped, it is identified as one of the emerging stock market, due to efforts of the Sri Lanka Government initiatives to improve the stock exchange service and to encourage more foreign participations. The Colombo stock market is an important market which plays a prominent role in the Sri Lankan economy. With regards to the stock market of Sri Lanka, to this date only a few studies have focused on Sri Lankan stock market [22-24]. As an outcome of literature survey, note that no study has been conducted to understand the macroeconomic risk factors that initiate uncertainty in the performance of the CSE. On the other hand, even though early empirical studies have indicated that fundamental economic activities in developed countries are directly or indirectly linked to stock market indexes, it is unclear whether such a relationship exists for emerging stock markets in developing countries as these stock exchanges are smaller in volume and relatively illiquid. In addition, as Bilson et al. [10] claim, the economies of emerging countries could be influenced by global economic indicators rather than domestic economic measures. Further, as Gunasekarge et al. [22] specify, the growing influence of foreign investors in these markets, following their introduction to international investment inflows, could actually weaken any link between national economic variables and share returns. According to the above reasons the behaviour of market indexes in Sri Lanka, may not be tied to economic fundamentals; rather the stock prices could be driven by the speculative activities of irrational investors. Therefore this paper attempts to identify the impact of 
macroeconomic condition on risk and returns of the Sri Lankan stock market. To answer the foresaid research question, following research objectives can be formed and estimated:

1. Determine whether Colombo stock market exhibits the semi strong form of market efficiency by investigating how macroeconomic variables (interest rate, inflation, money supply, exchange rate) affect share market returns of the Colombo Stock Exchange.

2. Determine how long it takes Colombo stock market to fully adjust previous economic shocks by examining the speed of adjustment to long-run equilibrium.

3. Determine whether macroeconomic condition are significant risk factors of stock returns by modelling volatility of macroeconomic factors influencing the volatility of the returns on stock.

4. Determine whether stock market movements are a leading indicator in formulating economic stabilization policies in Sri Lanka.

\section{Development of hypothesis}

This research observes the effects of macroeconomic variables on stock market returns and the volatility in the emerging Sri Lankan Stock Market and in order to achieve the objective of the study, the following hypotheses are developed.

\section{Hypothesis to support VAR based analysis}

$\mathrm{H}_{1}$ : Increase in interest rates has a negative impact on the stock returns.

$\mathrm{H}_{2}$ : Increase in inflation has a negative impact on the stock returns.

$\mathrm{H}_{3}$ : Increase in money supply has a positive impact on the stock returns.

$\mathrm{H}_{4}$ : Depreciation of exchange rate has a negative impact on stock returns.

\section{Hypothesis to support GARCH based analysis}

$\mathrm{H}_{5}$ : The shock to macroeconomic variables (interest rate, inflation, money supply, exchange rate) has impact on the stock market volatility in Sri Lanka.

\section{Research Design}

This part of the paper devotes to develop the econometric models used in the data analysis and to operationalize the concepts in hypothesis. With a view to achieve the stipulated set of research objectives, different econometric methods have been employed. The discussed conceptual framework indicates that when the stock prices reflect past changes in macroeconomic condition, the market is weak form. In particular, VAR based econometric models are employed to identify the market efficiency in the CSE and to test out first four hypothesis. These models include unit root tests, co-integration tests and error correction models. GARCH family econometric models are employed to identifying the share returns and market volatility in CSE.

\section{Model development}

This part of the thesis provides an overview of the statistical model employed and econometric test performed to identify the impact of macroeconomic variables on risk and returns of the stock market in Sri Lanka.
The research design is entirely based on the time series data and therefore the initial step of the estimation process is to ascertain the stationarity of the time series data. According to empirical study of Nelson and Plosser [83], non-stationarity is the fundamental issue of concern when dealing with economic time series data as most macroeconomic time series is correlated with time, indicating a trend. The estimated results using the non-stationary data will lead spurious results [84]. Hence, in obtaining meaningful estimation Augmented Dickey Fuller Test [85] and Phiillips and Perron [86] are employed on all-time series variables.

Equation 1- Log Filtered Basic Regression Model

$$
\log I N D X_{t}=\beta_{0}+\beta_{1} T B R_{t}+\beta_{2} I N F_{t}+\beta_{3} \log M S I_{t}+\beta_{4} \log E X R_{t}+u_{t}
$$

Where

$\log A S P I_{t}$

$\beta_{0}$ $=$ Log filtered Monthly value of All Share Price Index $=$ Intercept of the regression

$\beta_{1}, \beta_{2}, \beta_{3}, \beta_{4}$ $=$ Coefficient of variables

$T B R_{t}$

$I N F_{t}$

$\log M S I_{t}$ =Monthly average three months treasury bill rate

$\log E_{t}$ $=$ Monthly Inflation

$U S D$

$$
=\text { Regression Error term. }
$$

The presence of unit roots in data series provides an indication of the existence of a possible long-run relationship among the variables. Granger Representation Theorem introduced an econometric method (Co-integration method) to analyze non-stationary data without losing long run information caused with de-trending or differencing of data. After identifying the data series is non-stationary at level, cointegration analysis has been used to examine whether there is any long run equilibrium relationship. Out of the Engle and Granger [34] cointegration test and the Johansen and Juselius [35] co-integration test models to examine the long run relationships, this study is limited to use Johansen and Juselius [35] co-integration test (JJ approach) as it is more suitable and convenient to use in multivariate analysis.

The VAR models are usually employed to examine the interrelationship between share market behaviour and macroeconomic variables. However, VAR based models are not sophisticated enough to account for the stylized facts embodied in financial time series in general and share market returns in particular [87]. These stylized factors often violate the assumption of homoscedasticity (constant variance) in financial time series data and therefore Ordinary Least Squared (OLS) method is not adequate to analyze time series with nonconstant variance over time. Accordingly, this study motivates to go further and employ GARCH based model to determine the volatility in CSE in broadly and to identify the stylized facts of volatility clustering and leverage effect.

In general, financial and economic time series are noted to depend on its past value (autoregressive), and exhibits heteroskedasticity. Financial time series are found to have three main properties namely volatility clustering (volatility drastically changes over time), leverage effect and leptokurtosis [36]. As noted by Mandelbort [17] share market returns frequently exhibit the volatility clustering against the simple random walks. This is a period of high price volatility in the 
market, which tends to be followed by periods of high price volatility, and similarly low volatility periods tend to be followed by low volatility periods. In addition, it is anticipated that share market returns to exhibit asymmetric volatility or so called leverage effect. In general, the leverage effect refers to the negative correlation between a stock returns and volatility changes. This says that, the share market volatility from the bad news is greater than the volatility causes from the good news. In this study, the volatility in stock market returns and macroeconomic variables are estimated using the EGARCH model.

\section{Data and sample}

The data used for the study include four macroeconomic variables and share price indexes complied by CSE. Monthly time series data for the period from January 1998 to March 2016 is considered as making use of 228 data points adequate enough for doing unbiased and consistent analysis. The starting month of the sample period is determined by the availability of the money supply data that corresponds with first compiling of broad money monthly statistic. Monthly stock market index value is collected from the "data library" compact disc (CD) available at the CSE statistical department while the macroeconomic variables are collected from the statistic page of Central Bank of Sri Lanka (CBSL) web site.

This study investigates four macroeconomic variables that have long run and short run impact on the general share price index of Colombo stock market, namely All Share Price Index (ASPI). This is the principal share index that has been compiled based on market capitalization where market capitalization is obtained as a product of current market price and weight (weighting of shares is conducted in proportion to the issued ordinary capital of the listed companies). It measures the price fluctuations of all listed companies. The base year of ASPI is 1985 with index value of 100 . Hence, it is the broadest and the longest measure of the Sri Lankan share market. In addition to market capitalization, ASPI confine other performances of the market like liquidity, and turnover ratio. Therefore, ASPI is used as a tool to represent the characteristics of all listed shares in CSE. Monthly index values are extracted by recognizing the last trading date of each month $\log$ filtered data at month $t$ is used in the model to smooth possible volatility.

The data on the macroeconomics variables was extracted from the annual reports and publications of the Central Bank of Sri Lanka. The 91 days primary market t-bills rate (TBR) was used as a measurement of nominal interest rate. Year on year changes in the Colombo consumer price Index (CCPI) compile by the Department of Census and Statistics (which reflects the percentage change in consumer price index in particular month with that of last year)was employed to measure the rate of monthly inflation (INF). The broader money supply $M 2 b$ monthly value was used as the money supply (MSI) of the economy while the monthly average nominal exchange rate of US dollar (USD) to Sri Lankan Rupee (LKR) was to measure the foreign exchange rate (EXR).

All the time series, Logarithm All share price Index (LASPI), Treasury Bill Rate (TBR), Inflation (INF), Logarithm of Money Supply (LMSI), Logarithm of Exchange Rate (LEXR) shown in Appendix 1. The series LASPI, LMSI and LEXR seem to exhibit a trend in the mean since it has a clear upward slope. In fact, existence of upward or downward sloping patterns are signs of a non-constant mean which make the time series non-stationary [78].

TBR and INF carries irregular vertical fluctuation, showing that one part of the series differs greatly from the other. Thus indicating non-constant variance making the series non-stationary.

\section{Descriptive analysis}

Table 1 demonstrates the calculated summary statistics of selected exogenous and endogenous variables including mean maximum minimum values, standard deviation, skewness, kurtosis and the Jarque-Bera test statistics for data in level. All variables have been log flittered except treasury bill rate and inflation to smoothen out large fluctuation in financial and economic series. The standard deviation provides background information about the historical behaviour of the data. For instance, Treasury bill rate inflation and stock index is relatively more volatile compare to other variables.

Results in Table 2 exhibits that all variables are significantly skew either to negative or positive side. As Brooks [36] states if skewness coefficient is deviated from unity shows the extreme cases of skewness of a series. Generally, if the value of kurtosis is 3 and skewness is zero, that indicates series is normally distributed. Higher or lower kurtosis values represent extreme platykuritc or leptokurtic Brooks [36]. Hence as per the summary statistics all variables except inflation series are not normally distributed. Similarly, Jarque Bera statistics also provide evidence regarding the normality assumption. The estimated results indicate the JB statistic rejects the assumption of normality at 5 percent level of significance for all variables with the $p$ value less than 0.05. However, as Brooks [36] suggests non normality behaviour in economics and finance variables is not surprising.

\section{Empirical Analysis}

\section{Long run analysis}

The univariate $\mathrm{ADF}$ and PP unit root tests are applied for each variable following the methodology applied by Dickey and Fuller [85] and Phillips and Perron [86] testing for the significance of trend and

\begin{tabular}{|c|c|c|c|c|c|}
\hline Variable & LASPI & TBR & INF & LMSI & LEXR \\
\hline Mean & 7.432 & 11.27 & 9.6033 & 13.7767 & 4.5559 \\
\hline Median & 7.5073 & 10.78 & 8.3127 & 13.7503 & 4.6268 \\
\hline Maximum & 8.9616 & 21.3 & 29.8822 & 15.1833 & 4.8896 \\
\hline Minimum & 6.0004 & 5.74 & 0.1124 & 12.4703 & 3.9918 \\
\hline Std. Dev. & 0.9592 & 3.7102 & 5.9392 & 0.8113 & 0.2582 \\
\hline Skewness & 0.1204 & 0.6487 & 0.9105 & 0.0917 & -0.7727 \\
\hline Kurtosis & 1.58 & 2.4886 & 3.6722 & 1.7561 & 2.4743 \\
\hline Jarque-Bera & 19.9665 & 18.7176 & 36.2651 & 15.1494 & 25.6488 \\
\hline Probability & 0 & 0.0001 & 0 & 0.0005 & 0 \\
\hline
\end{tabular}

Table 1: This table reports descriptive statistics for the state variables and stock index in level. The state variables are the log stock market index (LASPI), treasury bill rate (TBR), inflation (INF), log money supply (LMSI) and log exchange rate (LEXR). The sample is 1998:1-2016:3. 
Citation: Fernando A (2018) Macroeconomic Impact on Stock Market Returns and Volatility: Evidence from Sri Lanka. Bus Eco J 9: 379. doi: $10.4172 / 2151-6219.1000379$

Page 8 of 15

\begin{tabular}{|c|c|c|c|c|}
\hline \multirow[t]{2}{*}{ Test variable } & \multicolumn{2}{|l|}{ ADF } & \multicolumn{2}{|c|}{ Phillips-Perron } \\
\hline & No Trend & Trend & No Trend & Trend \\
\hline \multicolumn{5}{|l|}{ Level } \\
\hline TBR & -2.52 & -2.52 & -2.54 & -2.66 \\
\hline INF & -1.56 & -1.56 & -2.7 & -2.84 \\
\hline LMSI & 0.35 & -2.27 & 1.11 & -2.49 \\
\hline LEXR & -2.22 & -2.1 & -2.23 & -1.69 \\
\hline LASP & -0.16 & -2.33 & -3.46 & -2.39 \\
\hline \multicolumn{5}{|c|}{ First difference } \\
\hline TBR & $-6.26^{* * *}$ & $-6.25^{* * *}$ & $-12.53^{\star * \star}$ & $-12.50^{* * *}$ \\
\hline INF & $-8.20^{* * *}$ & $-8.19^{* \star *}$ & $-12.16^{\star \star \star}$ & $-12.14^{\star * *}$ \\
\hline LMSI & $-3.38^{* *}$ & $-3.33^{* *}$ & $-14.35^{\star * *}$ & $-14.46^{* * *}$ \\
\hline LEXR & $-6.12^{* \star *}$ & $-6.35^{\star \star *}$ & $-10.20^{\star \star *}$ & $-10.31^{* * *}$ \\
\hline LASP & $-13.39^{* * *}$ & $-13.39^{\star * *}$ & $-13.51^{* * *}$ & $-13.50^{* * *}$ \\
\hline \multicolumn{5}{|c|}{ Test critical value } \\
\hline $1 \%$ level & -3.46 & -3.96 & -3.46 & -3.4 \\
\hline $5 \%$ level & -2.87 & -3.41 & -2.87 & -3.43 \\
\hline
\end{tabular}

Table 2: This table reports the Augmented Dickey fuller and Phillips -Perron unit root test results for the log stock market returns(LASPI), treasury bill rate (TBR), inflation (INF), log money supply (LMSI) and log exchange rate (LEXR). The 1st column of each test, reports the results when only an intercept term is incorporated into the model as a deterministic regressor while the 2 nd statistic column of each test reports the results when both an intercept term and a trend are included in the model. The test statistics are reported for each of the variables.

\begin{tabular}{|l|l|l|l|l|}
\hline Null hypothesis & Alternative hypothesis & Trace test & $\mathbf{5 \%}$ Critical value & Maximum Eigevalues Test \\
\hline $\mathrm{r}=0$ & $\mathrm{r}=1$ & 87.71154 ** & 69.81889 & $40.402177^{* *}$ \\
\hline $\mathrm{r} \leq 1$ & $\mathrm{r}=2$ & 47.30937 & 47.85613 & $28.93977^{* *}$ \\
\hline $\mathrm{r} \leq 2$ & $\mathrm{r}=3$ & 18.3696 & 29.79707 & 11.41472 \\
\hline $\mathrm{r} \leq 3$ & $\mathrm{r}=4$ & 6.954882 & 15.49471 & 6.899516 \\
\hline $\mathrm{r} \leq 4$ & $\mathrm{r}=5$ & 0.055366 & 3.841466 & 0.055366 \\
\hline ** Indicate statistical significance at 5\% level. & & & 21.58734 \\
\hline
\end{tabular}

Table 3: Cointegration Test Results: This table reports the test statistics of trace test and maximum tests for respective cointegration equations in Johansen test. The critical values donate rejection of the hypothesis at 5 percent significance level.

no trend assuming that the lags selection are based on guaranteed non-residual autocorrelation. The presented results indicate t-statistic (tau) values of all variables are larger than the critical value. Hence, test results fail to reject the null hypothesis of the presence of unit root at level.

Further, after applying the first difference I (1) to the time series, series became stationary at 5 percent and 1 percent level of significance. The PP test has conducted to reach robust conclusion about the test result. The results of the ADF test are further ensured by the result of the Phillip-Perron.

These results are consistent with the results of prior studies using Sri Lanka share markets data. The unit root test results of previous study in Sri Lankan context by Gunasekarage et al. [22] shows that ASPI, consumer price index, money supply, and exchange rate are stationary at first difference except treasury bill rate (as measure of interest rate) which is stationary in level. However, this study results shown treasury bill rate stationary only at first difference as opposed to Gunsekarage's results. This may be due to extreme fluctuations in treasury bill rate in 2001 and 2008 (Their sample period was 1985 to 2001).

The presence of unit root in data series is an indication of a possible existence of long term relationship among the variables. To explore whether there is any long-run relationship between Sri Lanka stock markets and macro-economic variables of interest rate, inflation, money supply and exchange rate Johansen and Juselius [35] cointegration test has been applied. The next step is to select appropriate lag lengths, as lag length misspecification in the model might generate auto correlated errors. Johansen co-integration test is sensitive to the lag length specifications and where by provides different co-integration test results [88]. Three different criteria namely the Akaike Information Criterion (AIC), the Schwarz Information Criterion (SIC), and the Hannan-Quinn information criterion (HQ) are used to select the lag lengths used in the VAR. Based on the results of the AIC and the HQ criteria, optimal lag length of 2 has been selected to perform cointegration test.

Table 3 presents the co-integration test results for the proposed equation including the trace test and the max-eigenvalue test at the 5 percent significance level. According to the results presented, null hypothesis of no co-integration among the variables has been rejected by the trace test statistics, while supporting co-integrating vector one at the 5 percent significance level. The max-eigenvalue test supports two co-integrating vectors at the 5 percent significance level. This establishes the fact that these macroeconomic variables affect Sri Lanka's capital markets in the long term, when the market forces are reacting actively. The Johansen-Juselius cointegration test results confirm the existence of long run relationship between selected macroeconomic variables. The long run relationship between stock returns and macroeconomic variables in Sri Lankan economy is consistent with prior empirical studies conducted in both developed and developing stock markets $[32,33,52,78]$.

The estimated results of normalized co-integrating vector tests and these statistics conclude that, all macroeconomic variables are statistically significant in the long run relationships between ASPI and the macroeconomic variables. 
Further detail, indicates that there is a significant negative long run relationship between TBR and ASPI which is in line with well proven portfolio management theory. Such results support the first hypothesis developed. The Treasury bill rate works as the rate of returns offered by the risk free assets. Hence, the investor's decision on shifting of funds between risky equity and risk free assets is extensively influenced by the movements in Treasury bill rate. High-treasury bill rates tend to encourage investors to purchase more government instruments. Hence with the increase in TBR will tend to reduce the demand for shares and causes an eventual reduction in share index. Therefore, it seems the money and capital markets in the Sri Lankan economy are substitutes in the long run. This negative relationship is between stock returns and the interest rate is consistent with those found in USA [11], Japan [52], China [89] Greece [90], Norway [13], Turkey and India [78]. There is a positive long run relationship between inflation and market index in contrasting to our initial expectations. The positive relationship implies that investors are compensated for inflation with the increased returns. Hence, the ASPI might not be used as a hedge against inflation as investors demand higher returns to pay off high inflationary rates.

The positive coefficient of money supply indicates that increasing money supply has a positive effect on ASPI. Chen et al. [12] stated that changes in the money supply are an important macroeconomic variable affecting stock returns. Originating from the expansionary monetary policy, as an economic stimulus, an increase in money growth results an unexpected boost in the public's cash balance, caused through the 'wealth effect'. The wealth effect tends to stimulate consumption and production there by stimulating investment. A considerable share of increased wealth would shift to bonds and stocks and amplify investment in securities, and consequently hike up the price of securities. An increase in the money supply would also reduce interest rates and encourage investment, consumption, and production. Although Chen et al., [12] provides this reason for Taiwan share market, it may similarly be applicable to Sri Lanka. An increase in money supply through usually reacts positively to stock market index has numerous implications with regard to monetary policy. Any changes in money supply will have a direct impact on equity markets and share indexes. Finally, supporting our fourth hypothesis, there is a significantly negative relationship between exchange rate and stock returns.

\section{Short run analysis}

According to Jansen [91] co-integration analysis alone, does not provide estimates with structural interpretations on the magnitude of the parameters of the co-integrating vectors. Therefore by following co-integration procedures, it is clear that short run dynamics in the long- run stock price index are estimated through incorporating an error-correction model. The VECM estimates support the short run relationship between stock returns and macroeconomic variables. A negative and significant error correction term in the model indicates the speed of adjustment to the long run equilibrium level.

The Table 4 depict results of the vector error correction model including the error correction term (ECM $(-1))$. Theoretically, the estimated coefficient of the ECM $(-1)$ is meaningful as it is negative and significant at 10 percent level. This indicates that in the absence of exogenous shocks, deviation of the ASPI from its long term path is corrected by 4.1 percent per month which is relatively slow. The implication of the speed of adjustment is that, if there is a shock to the macroeconomic variables ASPI will require about 24 months to return to the long run equilibrium. This result indicates that the selected determinants are significant variables for the long run co-integration estimation vector, while also having a significant short run impact on ASPI movements. In a sense, the short run analysis suggests that the Sri Lankan stock market is not efficient and therefore brings arbitrage opportunities for investors.

The $R 2$ value of the model is 16 percent, which means only 16 percent of the variations in ASPI is explained by Treasury bill rate, inflation, money supply and the exchange rate. Hence, these results establish the fact that, there are many other factors influencing the fluctuations on ASPI. The overall significance of the model is measured using the F-statistic value of 5.26 which is significant at 5 percent level. In the case of an unbiased consistent regression model, the residual should not be heteroskedasticity, no serially correlated and should be normally distributed. Therefore, arrays of various regression diagnostic tests have been conducted on the residual. This part of the analysis discusses the results from that. Before using an estimated equation for statistical inference, it is required to conduct the examination on residuals to illustrate evidence of serial correlation. The Breusch-Godfrey Lagrange Multiplier (LM test) test has been used to check evidence of serial correlations. In the test results larger $p$ values of LM statistics and F-statistics and LM test statistic 3.2 is less than chi squared test statistic with one degree of freedom of 3.841 support no serial correlation. Hence the null hypothesis of serial correlation has been rejected at 5 percent significance level and concludes that residuals are free from serial correlation. Heteroskedasticity of residuals has been test using Breusch- Pagan and test statistic does not reject the null hypothesis of no heteroscadasticity which is desirable. Based on test results depicted in the Table 5 residuals are not heteroscadatic at 5 percent significance level. The normality for ASPI has been tested using Jarque-Bera test. Since $\mathrm{p}$-value of the Bera-Jarque statistic is greater than 0.05 and the JB statistic is less than 5.99, indicating that null hypothesis is not rejected. Thus test results as expounded by Table 6 signify that the distribution of error term of ASPI is independent and normal.

\section{Analysis of volatility}

Early part of the analysis shows that the Sri Lankan stock returns has short term and the long term relationship between selected macroeconomics variables. After establishing the impact of macroeconomic variables on stock market returns, this part of the analysis is allocated to examine how macroeconomic variables act as risk factors influencing the stock market volatility and uncertainty in the context of Sri Lanka.

The stationary test result shows the stock index is not stationary in level and become stationary at first differentiation. Given that, other statistical properties of all share price index are examined to

\begin{tabular}{|l|l|l|l|l|}
\hline Regressor & TBR & INF & LMSI \\
\hline Coefficient & $-0.058507^{* *}$ & $0.045649^{* *}$ & $1.784065^{\star *}$ \\
\hline Standard Error & -0.01318 & -0.00772 & -0.11019 \\
\hline t-statistics & {$[-4.43797]$} & {$[5.91658]$} & {$[16.1910]$} \\
\hline$* *$ & {$[-7.56439]$} \\
\hline
\end{tabular}

** Indicate statistical significance at $5 \%$ level.

Source; Authors Calculations using E-views 8.

Table 4: Long Run Relationship Coefficients:- This table reports the estimated generalized coefficient of the treasury bill rate (TBR), inflation (INF), log money supply (LMSI) log exchange rate (LEXR) and associated standard errors and t-statistics. 
Citation: Fernando A (2018) Macroeconomic Impact on Stock Market Returns and Volatility: Evidence from Sri Lanka. Bus Eco J 9: 379. doi: $10.4172 / 2151-6219.1000379$

Page 10 of 15

\begin{tabular}{|c|c|c|c|}
\hline Variable & Coefficient & Standard Error & t-Statistics \\
\hline $\operatorname{ECM}(-1)$ & -0.04115 & -0.02369 & {$[-1.74345]^{*}$} \\
\hline $\mathrm{D}($ LASPI $(-1))$ & 0.075777 & -0.07253 & [ 1.04473$]$ \\
\hline $\mathrm{D}($ LASPI(-2)) & -0.02325 & -0.07141 & {$[-0.32564]$} \\
\hline $\mathrm{D}(\mathrm{TBR}(-1))$ & -0.01245 & -0.00676 & {$[-1.84051]^{*}$} \\
\hline $\mathrm{D}(\mathrm{TBR}(-2))$ & -0.00553 & -0.0065 & {$[-0.85034]$} \\
\hline $\mathrm{D}(\operatorname{INF}(-1))$ & 0.00312 & -0.0026 & [ 1.19810$]$ \\
\hline $\mathrm{D}(\mathrm{INF}(-2))$ & -0.0037 & -0.00265 & {$[-1.39674]$} \\
\hline $\mathrm{D}(\mathrm{LMSI}(-1))$ & 0.398644 & -0.56754 & [ 0.70241] \\
\hline $\mathrm{D}(\mathrm{LMSI}(-2))$ & -0.05855 & -0.56669 & {$[-0.10332]$} \\
\hline $\mathrm{D}(\operatorname{LEXR}(-1))$ & -0.04722 & -0.50331 & {$[-0.09382]$} \\
\hline $\mathrm{D}(\operatorname{LEXR}(-2))$ & -0.24605 & -0.49053 & {$[-0.50160]$} \\
\hline R squared & 0.160733 & & \\
\hline F-statistic & $5.263813^{\star \star}$ & & \\
\hline \multicolumn{4}{|c|}{ Serial Correlation LM Test: Breusch-Godfrey } \\
\hline Obs* R-squared & 3.20116 & Prob. Chi-Square & 0.2018 \\
\hline \multicolumn{4}{|c|}{ Heteroskedasticity Test: Breusch-Pagan-Godfrey } \\
\hline Obs*R-squared & 19.60866 & Prob. Chi-Square(15) & 0.1875 \\
\hline \multicolumn{4}{|l|}{ Normality Test: } \\
\hline Jarque- Bera & 1.031505 & Probaility & 0.597051 \\
\hline
\end{tabular}

Table 5: Vector Error Correction Model Estimates:- VECM estimation results reports in this table. This table presents the estimated coefficient of error correction term (ECM) and the 1st and 2nd lag period coefficients of the log stock market returns (LASPI), treasury bill rate (TBR), inflation (INF), log money supply (LMSI), log exchange rate (LEXR) and associated standard errors and t-statistics. 2nd part of the table donates the test statistics represent the model adequacy and the model fitness.

\begin{tabular}{|c|c|c|c|c|c|}
\hline \multicolumn{6}{|l|}{ Panel a: The Mean Equation } \\
\hline Coefficients & Model 1 & Model 2 & Model 3 & Model 4 & Model 5 \\
\hline \multirow[t]{2}{*}{ Constant } & 9.33 & 7.69 & 4.16 & 10.32 & 5.97 \\
\hline & {$[0.0000]$} & [0.0000] & {$[0.0078]$} & {$[0.0000]$} & [0.0638] \\
\hline \multirow[t]{2}{*}{ DASPI(-1) } & 0.19 & 0.12 & 0.15 & 0.11 & 0.13 \\
\hline & {$[0.1087]$} & [0.0446] & {$[0.0089]$} & {$[0.0562]$} & {$[0.0278]$} \\
\hline \multicolumn{6}{|l|}{ Panel b: The Variance Equation } \\
\hline \multirow[t]{2}{*}{ Asymmetric Term } & $-0.12^{* * *}$ & $-0.12^{* * *}$ & $-0.14^{* * *}$ & $-0.17^{* \star *}$ & $-0.12^{* * *}$ \\
\hline & {$[0.0000]$} & [0.0000] & {$[0.0000]$} & {$[0.0000]$} & {$[0.0000]$} \\
\hline \multirow[t]{2}{*}{ EGARCH } & $0.98^{\star * *}$ & $0.98^{\star * *}$ & $0.98^{* * *}$ & $0.99^{\star * *}$ & $0.98^{* * *}$ \\
\hline & {$[0.0000]$} & {$[0.0000]$} & {$[0.0000]$} & {$[0.0000]$} & {$[0.0000]$} \\
\hline \multirow[t]{2}{*}{ DTBR } & & $-0.68^{* *}$ & & & \\
\hline & & [0.0356] & & & \\
\hline \multirow[t]{2}{*}{ DINF } & & & -0.06 & & \\
\hline & & & [0.1103] & & \\
\hline \multirow[t]{2}{*}{ DLMSI } & & & & $10.86^{* * *}$ & \\
\hline & & & & {$[0.0000]$} & \\
\hline \multirow[t]{2}{*}{ DLEXR } & & & & & -3.07 \\
\hline & & & & & [0.2478] \\
\hline \multicolumn{6}{|c|}{ Panel c: Diagnostic Test Results } \\
\hline ARCH-LM Test & {$[0.6500]$} & [0.3921] & {$[0.2583]$} & [0.4353] & [0.4528] \\
\hline Jarque-Bera & [0.2173] & [0.1923] & {$[0.0605]$} & {$[0.3070]$} & [0.0834] \\
\hline \multicolumn{6}{|c|}{$\begin{array}{l}{ }^{* * *} \text { and }{ }^{* *} \text { Indicate statistical significance at } 1 \% \text { and } 5 \% \text { level respectively. } \\
\text { Source- Author's Calculations using E-views } 8\end{array}$} \\
\hline
\end{tabular}

identify the stylized fact and the descriptive statistics for monthly stock returns of the Sri Lankan stock market index given in Appendix 2. The unconditional standard deviation of the stock returns shows the market index was relatively highly volatile during the sample period. The kurtosis coefficient of 11.28 implied returns is seriously departed from the normality. Non normal distribution of the series further emphasis by the Jarque Bera test statistic and has asymmetric tails skewed to the write. In the market point of view this findings suggest investors in the CSE are likely to earn positive returns.

Another stylized factor in the financial theory (as put forward by Mandelbrot [17]) is volatility clustering which implies strong autocorrelation in returns. In simple terms, the period of higher volatility are followed by the period of higher volatility [37]. The plotted graph of the stock returns is provides visual evidence of the existence 
of volatility clustering in the Colombo Stock Market (Appendix 3). This result is further confirmed by the calculation of correlogram of squared residual of stock returns. According to the test statistics if there is no auto correlation in the residual of the stock returns, partial autocorrelation and the auto should be nearly zero for all lags and Q statistic need to be insignificant with higher $\mathrm{p}$ value.

However, as depicted in Appendix 4 stock market returns rejects the null hypothesis of no autocorrelation for all 36 lags and provide evidence to present volatility clustering. The theoretical explanation for clustered volatility as given by Kirchler and Huber [92] is that new information creates higher volatility at the beginning of each period. This phenomenon of higher volatility leads to higher returns, associated with the investors' heterogeneous expectations. Kirchler and Huber [92] further argue that time series returns tend to decreases as investors learn from their trading strategies. As a result, the market moves to a partial equilibrium condition until new information arrives. Accordingly, test results presents the monthly returns of ASPI have ARCH effect and the stock returns series is not normally distributed. Therefore the GARCH based models are applied to analyze the volatility of stock market.

\section{Macroeconomic variables and stock market volatility}

The effect of changes in the macroeconomic variables on the stock market volatility is analyzed using the EGARCH $(1,1)$ model. At the initial stage of estimation, standard-alone mean equation is run to identify the asymmetric behaviour of the stock returns without incorporating macroeconomic risk factors to the variance equation. As shown in the estimated results in Table 6 , the value of the asymmetric coefficient is negative and statistically significant at 5 percent. In finance this is called leverage effect and is a negative correlation between past returns and future volatility of the returns. Higher the leverage effect greater the volatility for the stock market returns. It provides evidence to support presence of asymmetric volatility in the monthly stock returns. Meaning, this shows the bad news in the CSE has larger effects on the volatility of the stock market than the good news. Following Nelson [40], the study has used EGARCH model specification as a parsimonious representation for modelling conditional volatility of Sri Lankan stock market returns to capture asymmetries (derived from negative and positive shocks) in high frequent time series. Prior to the use the model to identify the impact of macroeconomic risk factors on the stock returns different diagnostic test conduct to ensure the fitness of the model.

Latter part of the Table 6 contains the diagnostic test results on the residuals generated from the EGARCH model. The ARCH LM test statistics and correlogram of squared residual suggests no serial correlation thereby confirming that estimated model produces residuals that are free from ARCH effect. Further, Jarque Bera statistic cannot reject the hypothesis of normality. Hence the diagnostic results support the adequacy of the model to estimate the volatility of the Colombo stock market with the macroeconomic risk factors.

Given that the estimate EGARCH $(1,1)$ model is appropriate to model the impact of macroeconomic variables on the stock market volatility during the sample period this section is dedicated to interpret the results obtained from the model. When the macroeconomic variables individually incorporate in to the variance equation, the results of the estimates show how changes in particular macroeconomic risk factors influence the stock market volatility. The results of such models suggest Inflation and exchange rate do not explain the stock market volatility.
Similarly, the results indicate that the stock market returns volatility has significantly negative relationship between the Treasury bill rates. This implies that when there is a shock to the interest rate in the economy that it would lead to a higher fluctuation in the stock market index and therefore the returns. Finally, relationship between stock market volatility and the money supply also seems statistically significant. Accordingly, out of four economic variables that expect to initiate macroeconomic risks, only interest rate and money supply are proven to introduce such risk to the volatility of the stock market returns in Sri Lanka.

\section{Robustness of the models}

As discussed earlier, with the protracted internal conflict coming to an end in May 2009, the CSE has recorded a remarkable growth of over 300 percent. Hence to check the robustness of results, the models are re-estimated for the sub sample period that represent the post war period of the Sri Lankan Economy. The sub sample period is consisted with the monthly time series data of all variables from June 2009 to March 2016 inclusive of 83 data points. The results of the JohansenJuselius co-integration test (Appendix 5) confirmed existence of long run relationship between selected macroeconomic variables and the stock returns. Similarly, the results found significant negative long run relationships between TBR/EXR and stock returns, while positive significant long run relationship are found between Money supply (MSI) and stock returns. In contrast to the principle study, INF is not the significant macroeconomic variable that cause on stock returns (Appendix 6). This may be due to monetary management in the Sri Lankan Economy based on the inflation target framework. The result of the VECM model indicates the speed at which adjustments occurs in the long term equilibrium, when negative and significant at 1 percent. The coefficient of ECM indicates 12.5 percent of previous disequilibrium in long run, which would then be corrected in short run. According to these results, it is revealed that time required to adjust the disequilibrium is less in post war period. This brings the positive signal to investors about the Colombo Stock Exchange. The implication of the speed of adjustment is that, if there is a shock to macroeconomic conditions, stock prices would require about 8 months to return to long run equilibrium as opposed to 24 months in the principal study. This implies that the Colombo market has started to react quicker, comparatively to macroeconomic changes.

The results of the EGARCH model estimations for the subsample period of June 2009 to March 2016 shows in the appendix 7 . The value of the asymmetric coefficient is negative and statistically significant at 5 percent and this is consistent with the results of our original estimation. The results of such subsample model again suggest Inflation and exchange rate do not explain the stock market volatility.

\section{Discussion and Conclusion}

\section{Management implication}

Stock market of every country plays a vital role in the evolution of their respective economies in terms of commerce and industry, which ultimately determines the development of the overall economy. No doubt, the argument is the same in terms of Sri Lanka, as it is an emerging economy in 21 st century. Therefore, different stakeholders keep an eye on the stock market and closely monitor its performance. These parties include, but are not limited to investors and other market participants, government, regulatory authorities of the stock market and academia.

The empirical results confirmed that macroeconomic variables 
affect the stock returns and macroeconomic shocks, significantly impacting the market volatility of the Sri Lankan stock market. Hence in the light of the above findings number of managerial implication are considered. From the view of investors, the study found that all macroeconomic variables are priced by the market. If all other factors that determine the stock returns remain equal, the changes in macroeconomic variables therefore create possibilities of earning excess returns. As suggested by Atlay [29], Norma and Robins [93] and Ekpenyong and Obieke [94] the optimal portfolio investment strategy for CSE therefore might be to buy shares immediately when there is an improvement to these macroeconomic variables [95].

From the perspective of policy makers, the findings provide useful insights for the formulation and implementation of macroeconomic policies to achieve financial market stability in an economy. When policy makers develop economic policies they should be feel free to make national macroeconomic policies without the fear of influencing capital creation and share trading process [96-102]. The results of this paper indicate that the interest rate has a negative and significant impact on the conditional stock market volatility. This implies that high treasury bill rates deteriorate the performance of CSE. Further, Positive impact of money supply and stock returns has implications on monetary policy in which, an increase in money supply will increase the stock returns. Hence, policymakers need to be careful when trying to influence the economy through changes in macroeconomic variables such as money supply and interest rates [103]. Even though the monetary policy should not be guided by the impact of the stock market, such influences should not be ignored as the fundamental and primary source of raising funds for business expansions is the share market. Hence, the share market is important from stand point of the industry and the investors. Prudent monetary policy management would stabilize the fluctuations in money supply and interest rates, as it would mitigate stock market volatility.

Further, stock market regulator; Security and Exchange Commission (SEC) could formulate different policies to ensure smooth trading and investment atmosphere. Further, they could formulate rules and regulations based on their knowledge of the predictable share price behaviour. In fact, the existence of a co-integrating relationship between macroeconomic variables and stock market indexes brings the doubt of efficient market hypothesis. Primarily, it may lead the investor to predict behaviour of stock prices and market indexes. This situation could lead to superior earning capabilities [104]. Therefore regulators may be required to reassess their regulatory systems, if the effect of stock market index is not something they desired.

These findings may have important implications on decision making of investors. Stock market, as a channel for investment is more risky. Hence investors always try to predict and forecast the trend of market indexes to gain abnormal benefits to avoid risks [105]. By understanding the relationship between macroeconomic variables and share indexes, investor might be able to forecast how market indexes are fluctuating in line with the changes in macroeconomic variables. If so, Investors would be able to ensure maximum return for their investments in share market by focusing on the varying significance of the economic risk factors [106]. Further the findings note that, domestic macroeconomic variables have varying impacts on ASPI and MPI which may be useful to manage portfolio diversification strategies effectively [107-115].

\section{Limitation of the study}

From the inferential statistics, the R square of the VECM indicates that only around 16 percent of the variations in ASPI are explained by Treasury bill rates, inflation, money supply and exchange rates [116]. These four macroeconomic variables represent only some of the fundamental macroeconomic indicators of an economy. Hence these results establish that probable exclusion of some other factors would better predict the movement of ASPI [117]. For instance, Gross Domestic Product (GDP) is not included in the model due to mismatch of sample frequency of data. However, GDP is an importance variable to be included in this study to represent the real activity of the economy [118]. Despite the fact that, Industrial Production (IP) has been used as a close proxy for the GDP by researchers in previous studies, it was decided not consider this variable in the study as IP ignores the nonfactory industrial sector, agricultural and service sector of the economy [119]. In Sri Lanka IP represent around 8-10 percent of the GDP [120]. Hence IP is not a sound approximation to GDP. Further the trade balance of Balance of Payment, which represents the cash inflows and out flows (net cash flows) of the economy has not been used, as the net cash flow carry negative figures which create estimation problems for the analysis. The selection of the four local macroeconomic variables, are not perfect as arguments could be made in favour of including other factors. Furthermore, applying a technical method such as principal component analysis to the model would have increased the explanatory power of the model [121].

The study uses the ASPI as a proxy to the stock returns in the Colombo Stock Market. In General stock returns should include both capital gain and the dividend income to identify the total returns on the holding stock portfolio. However, this Index includes capital gains of the stock returns, while excluding the dividend component [122]. Therefore it limits assessing the full impact of macroeconomic variables on actual stock returns. A study conducted based on the individual companies' stock returns will solve this limitation.

Finally, the study uses the secondary data to carry out various econometric tests. However using secondary data may not be the most accurate, as they do not represent the actual and whole impact of macroeconomic variables on stock returns as some of these macroeconomic variables may not be market driven [123]. To elaborate further, some of these variables may not be determined entirely based on market forces. For instance Exchange rate may not be free floating during the entire duration of the sample period. It is controlled by the political and economic policy decisions of the Government. This as a result, may weaken the measured results of this study.

\section{Direction for future research}

The results of this study create the platform for further research studies, in three main areas. First, the present study can be extended to sector indexes over a longer period with more macroeconomic variables. This will assist to explain how the different portfolios of stocks have been exposed to the selected macroeconomic variables. Second, this study can be extended to explore the causality between stock returns and macroeconomic variables in order to identify the bidirectional relationship between variables. Finally, this study used the past data for empirical analysis [124]. However, technically, the APT theory is intended to be based on expected economic conditions, while $\mathrm{EMH}$ is intended to be based on instantaneous macroeconomic news without delay. Therefore in addressing deficiencies associate with APT theory, the same econometric estimation procedure could be used, using expected time series data to estimate results [125]. Furthermore, in order to highlight the anomalies associate with $\mathrm{EMH}$, this study could be extended, to utilize instantaneous macroeconomic news based upon, on the spot announcements [126]. 
Citation: Fernando A (2018) Macroeconomic Impact on Stock Market Returns and Volatility: Evidence from Sri Lanka. Bus Eco J 9: 379. doi: 10.4172/2151-6219.1000379

Page 13 of 15

\section{Conclusion}

The results of the study conclude that, interest rate is one of the most prominent economic factors determining investment decisions. When there is a higher interest rate, it encourages investors to switch their investment from the risky equity investment to fixed income securities (whose return determined on interest rate). Such substitutional investment strategy creates lesser demand for stocks while higher supply of risky share investments reduces the price and returns of stocks. Accordingly, as results suggest there is a negative relationship between stock returns and interest rate.

The study establishes a positive long run relationship between inflation and stock market returns. This result holds the fisher hypothesis that state, the interest rate should fully adsorb expected inflation movements to maintain equilibrium interest rates. Further, this result implies that investors are compensated for inflation with the increased returns. Therefore, the ASPI might not be used as a hedge against inflation as investors demand higher returns to pay off for high inflation.

The positive long run relationship between money supply and stock returns support the modern quantity theory of money presented. Moreover, as indirect relationship, a positive money shocks has a positive impact on aggregate economy, thereby causing to increase stock prices. Higher economic activity ensures higher cash flows, which is expected to increase stock returns.

The negative relationship between stock returns and exchange rate emphasises depreciation in exchange rates making Sri Lankan equity comparatively cheaper to foreign investors. Also as Sri Lanka is relatively an import oriented country, a decrease in the inflation rate is expected to have a negative impact on the stock returns. Based on the above results, thesis successfully achieved the first objective of the study.

Addressing the second objective of the thesis, results of the short run analysis indicate that the stock market speed of adjustment to long run equilibrium is relatively slow. If there is a shock to the macroeconomic variables, ASPI will require about 24 months to return to long run equilibrium. Accordingly, short run analysis suggests that the Sri Lankan stock market is not efficient and therefore brings arbitrage opportunities for investors.

With respect to volatility of Sri Lankan stock Market, stock returns are found to have three main stylized factors; namely volatility clustering, leverage effect and leptokurtosis. The study concludes the presence of asymmetric volatility in the monthly stock returns. This shows that bad news in the CSE has larger effects on the volatility of the stock market than good news. When the macroeconomic variables are incorporated in to the variance equation of the EGARCH model, the stock market returns volatility has a negatively significant relationship between the Treasury bill rates. This implies there is a shock to the interest rate in the economy that will lead to higher fluctuations in the stock market index and the return.

This result further emphasizes the existence of active portfolio management in the Sri Lankan stock market. Finally, of the four economic variables that were expected to create macroeconomic risk, only Interest rate and money supply were proven to bring such risks to volatility of the stock market returns in Sri Lanka. Therefore, accomplishing third research objective, the study concludes macroeconomic condition creates significant risk on stock returns in the Colombo Stock Exchange. Accordingly, the paper as a whole, conclusively establishes that macroeconomic variables have a significant impact on stock market returns and volatility in the Sri Lankan market.

\section{References}

1. Chen NF, Roll R, Ross SA (1986) Economic forces and the stock markets. J Bus 59: 383-403.

2. Choi JJ, Hauser S, Kopekcy KJ (1999) Does the stock market predict real activity? Time series evidence from the G7 countries. J Bank Financ 23: 17711792.

3. Markowitz H (1952) Portfolio Selection. J Financ 7: 77.

4. Ross SA (1976) The arbitrage theory of capital asset pricing. J Econ Theory 13: $341-360$.

5. Burmeister E, Wall KD (1986) The arbitrage pricing theory and macroeconomic factor measures. Financ Rev 21: 1-20.

6. Fama EF, Malkiel BG (1970) Efficient capital markets: a review of theory and empirical work. J Financ 25: 383-417.

7. Fama EF (1981) Stock returns, real Activity, inflation and money. Am Econ Rev 71: 545-565

8. Fama EF, French KR (1988) Dividend yields and expected stock returns. Financ Econ 22: 3-25.

9. Asprem M (1989) Stock prices, asset portfolios and macroeconomic variables in ten European countries. Journal of Banking and Finance 13: 589-612.

10. Bilson CM, Brailsford TJ, Hooper VJ (2001) Selecting macroeconomic variables as explanatory factors of emerging stock market returns. Pac-Basin Financ $J$ 9: 401-426.

11. Bulmash SB, Trivoli GW (1991) Time-lagged interactions between stock prices and selected economic variables. J Portfolio Manage 17: 61-67.

12. Chen MH, Kim WG, Kim HJ (2005) The impact of macroeconomic and non macroeconomic forces on hotel stock reruns. J Hospitality Manage 24: 243-258.

13. Gjerde O, Saettem F (1999) Causal relations among stock returns and macroeconomic variables in a small open economy. J Int Financ Markets, Inst and Money 9: 61-74.

14. Wasserfallen W (1989) Macroeconomic news and the stock market. J Bank Financ 13: 613-626.

15. Veronesi $P$ (1999) Stock market overreaction to bad news in good times: A rational expectations equilibrium model. Rev Financ Stud 12: 975-1007.

16. Adam K, Marcet A, Nicolinl JP (2016) Stock Market Volatility and Learning. J Financ 71: 33-82.

17. Mandelbrot B (1963) The variation of certain speculative prices. J Bus 36: 394-419.

18. Black F (1976) Studies in stock price volatility changes. Proceedings of the 1976 Business Meeting of the Business and Economic Statistics Section, American Statistical Association, Washington, D.C.

19. Schwert GW (1989) Why does stock market volatility change over time? The Journal of Finance 44: 1115-1153.

20. Chan LKC, Karceski J, Lakonishok J (1998) The risk and return from factors. J Financ Quant Anal 33: 159-188.

21. Taylor S (2008) Modeling Financial Time Series, (2nd edn.), John Wiley and Sons, New York.

22. Gunasekarage A, Pisedtasalasai A, Power DM (2004) Macroeconomic influence on the stock market evidence from an emerging market in South Asia. J Emerg Market Financ 3: 285-304.

23. Menike LMCS (2006) The effect of macroeconomic variables on stock prices in emerging Sri Lankan stock market. Sabaragamuwa Univ J 6: 50-67.

24. Wickremasinghe $\mathrm{G}$ (2011) The Sri Lankan stock market and the macroeconomic: An empirical investigation. Stud Econ Financ 28: 179-195.

25. Roll R, Ross SA (1980) An empirical investigation of the arbitrage pricing theory. J Financ 35: 1073-1103.

26. Chen NF (1983) Some empirical tests of the theory of arbitrage pricing. $J$ Financ 38: 1393-1414. 
Citation: Fernando A (2018) Macroeconomic Impact on Stock Market Returns and Volatility: Evidence from Sri Lanka. Bus Eco J 9: 379. doi: 10.4172/2151-6219.1000379

27. Kryzanowski L, To M (1983) General factor models and the structure of security returns. J Financ Quant Anal 18: 31-52.

28. Dhrymes P, Friend I, Gultekin B (1984) A Critical re-examination of the empirical evidence on the arbitrage pricing theory. J Financ 39: 323-346.

29. Altay E (2003) The effect of macroeconomic factors on asset returns: A comparative analysis of the German and the Turkish stock markets in an APT framework. EconWPA

30. Choi JJ (1995) The Japanese and US stock prices: a comparative fundamental analysis. JPN World Econ 7: 347-360.

31. Brooks C, Tsolacos S, Lee S (2000) The cyclical relations between traded property stock prices and aggregate time-series. J Prop Investment Financ 18: 540-564.

32. Gan CL, Yong HHA, Zhang J (2006) Macroeconomic variables and stock market interactions: New Zealand evidence. Investment Manage Financ Innov 3: 89-101.

33. Ratanapakorn O, Sharma SC (2007) Dynamic analysis between the US stock return and the macroeconomic variables. Appl Financ Econ 17: 369-377.

34. Engle RF, Granger CWJ (1987) Cointegration and error correction: representation estimation and testing. Econometrica 55: 251-276.

35. Johansen S, Juselius C (1990) Maximum likelihood estimation and inference on cointegration-with applications to the demand for money. Oxford Bull Econ Stat 52: 169-210

36. Brooks C (2002) Introductory Econometrics for Finance, (1st edn.), Cambridge University Press, London.

37. Francq C, Zakoian JM (2010) GARCH Models; Structure, statistical inference and Financial applications, 1st edn, John Wiley and Sons, New York.

38. French KR, Schwert GS, Stambaugh RF (1987) Expected stock returns and volatility. J Financ Econ 19: 3-29.

39. Schwert GW (1990) Stock market volatility. Financ Anal J 31: 23-34

40. Nelson DB (1991) Conditional hetroskedasticity in asset returns: A new approach. Econometrica 59: 347-370.

41. Campbell JY, Hentschel $L$ (1992) No news is good news: an asymmetric mode of changing volatility in stock returns. J Financ Econ 31: 281-318.

42. Duffee GR (1995) Stock returns and volatility: A firm level analysis. J Financ Econ 37: 399-420.

43. Giot $P$ (2005a) Relationships between implied volatility indexes and stock index returns. J Portfolio Manage 31: 92-100.

44. Giot P (2005b) Implied volatility indexes and daily value at risk models. $J$ Derivatives 12: 54-64.

45. Banerjee PS, Doran JS, Peterson DR (2007) Implied volatility and future portfolio returns. J Bank Financ 31: 3183-3199.

46. Hibbert AM, Daigler, RT, Dupoyet B (2008) A behavioural explanation for the negative asymmetric return-volatility relation. J Bank Financ 32: 2254-2266.

47. Becker R, Clements AE, McClelland A (2009) The jump component of SandP 500 volatility and the VIX index. J Bank Financ 33: 1033-1038.

48. Lee BS (2010) Stock returns and inflation revisited: An evaluation of the inflation illusion hypothesis. J Bank Financ 34: 1257-1273.

49. Campbell JY (1987) Stock returns and the term structure. J Financ Econ 18: 373-399.

50. Fama EF, Schwert GW (1977) Asset returns and inflation. J Financ Econ 5: $115-146$.

51. Zhou C (1996) Stock market fluctuations and the term structure, board of governors of the federal reserve system. Financ Econ Discuss Series.

52. Mukherjee TK, Naka A (1995) Dynamic relations between macroeconomic variables and the Japanese stock market: An application of a vector error correction model. J Financ Res 18: 223-237.

53. Chan KC, Chen N, Hsieh DS (1985) An exploratory investigation of the firm size effect. J Financ Econ 14: 451-471.

54. Beenstock M, Chan K (1988) Economic forces in the London stock market Oxford Bull Econ Stat 50: 27-39.
55. Jaffe JF, Mandelker G, Miller KD (1976) The fisher effect for risky assets: An Empirical Investigation. J Financ 31: 447-458.

56. Choudhry T (2001) Inflation and rates of return on stocks: evidence from high inflation countries. J Int Financ Markets, Inst, Money 11: 75-96.

57. Nelson CR (1976) Inflation and rates of return on common stocks. J Financ 31: $471-448$

58. Bodie Z (1976) Common stocks as a hedge against inflation. J Financ 31: 459-470.

59. Firth M (1979) The relationship between stock market returns and rates of inflation. J Financ 34: 743-749.

60. Boudoukh J, Richardson M (1993) Stock returns and inflation: A long-horizon perspective. Am Econ Rev 83: 1346-1355

61. Engsted T, Tanggaard C (2002) The relation between asset returns and inflation at short and long horizons. J Int Financ Markets, Inst Money 12: 101-118.

62. Friedman M, Schwartz AJ (1963) Money and business cycles. Rev Econ Stat 45: 32-64.

63. Bernanke BS, Kuttner KN (2005) What explains the stock market's reaction to Federal Reserve policy? J Financ 60: 1221-1257.

64. Homa KE, Jaffee DM (1971) The supply of money and common stock prices J Financ 26: 1045-1066.

65. Booth RJ, Booth LC (1997) Economic factors, monetary policy and expected returns on stocks and bonds. Econ Rev Fed Reserve Bank of San Francisco 2: $32-42$.

66. Sellin P (2001) Monetary Policy and the stock market: Theory and empirical evidence. J Econ Surv 15: 491-541.

67. Frankel JA (1983) Monetary and portfolio-balance models of exchange rate determination in economic interdependence and flexible exchange rates. MIT Press, Cambridge MA

68. Dornbusch R, Fischer S (1980) Exchange rates and current account. Am Econ Rev 70: 960-971.

69. Barrows CW, Naka A (1994) Use of macroeconomic variables to evaluate selected hospitality stock returns in the US. Int J Hospitality Manage 13: 119-128.

70. Lee BS (1992) Casual relations among stock returns, interest rate, real activity and inflation. J Financ 47: 1591-1603.

71. Roll R, Ross SA (1984) A critical re-examination of the empirical evidence on the arbitrage pricing theory: A Reply. J Financ 39: 347-350

72. Roll R, Ross SA (1995) The arbitrage pricing theory approach to strategic portfolio planning. Financ Anal J 51: 122-131.

73. Apergis N, Eleftheriou S (2002) Interest rates, inflation, and stock prices: the case of Athens stock exchange. J Policy Model 24: 231-236.

74. Chancharoenchai K, Dibooglu S, Mathur I (2005) Stock returns and the macroeconomic environment prior to the Asian crisis in selected Southeast Asian countries. Emer Markets Financ Trade 41: 38-56.

75. Kang J, Kim TS, Lee C, Min BK (2011) Macroeconomic risk and the cross section of stock returns. J Bank Financ 35: 3158-3173.

76. Chand S, Kamal S, Ali I (2012) Modeling and volatility analysis of share prices using arch and GARCH models. World Appl Sci J 19: 77-82.

77. Rapach DE, Strauss JK, Zhou G (2013) International stock return predictability: what is the role of the United States? J Financ 68: 1633-1662.

78. Ahmed S (2008) Aggregate economic variables and stock market in India. Int Res J Financ Econ 14: 141-162.

79. Maysami RC, Howe LC, Hamaz MA (2004) Relationship between macroeconomic variables and stock market indexes: cointegration evidence from stock exchange of Singapore's All-S sector indexes. J Penguruson 24 47-77.

80. Brown SJ, Weinstein MI (1983) A New approach to testing asset pricing models: The Bilinear paradigm. The J Financ 38: 711-744.

81. Security and Exchange commission of Sri Lanka 2014, Capital Market Progress Report, viewed 28 August 2015

82. Security and Exchange commission of Sri Lanka 2016, Annual Report. 
Citation: Fernando A (2018) Macroeconomic Impact on Stock Market Returns and Volatility: Evidence from Sri Lanka. Bus Eco J 9: 379. doi: 10.4172/2151-6219.1000379

83. Nelson CR, Plosser Cl (1982) Trend and random walks in macroeconomics time series. J Monet Econ 10: 139-162.

84. Granger CWJ, Newbold P (1974) Spurious regressions in econometrics. J Econometrics 2: 111-120.

85. Dickey DA, Fuller WA (1981) Likelihood ratio statistics for autoregressive time series with unit root. Econometrica 49: 1057-1074

86. Phillips PCB, Perron $P$ (1988) Testing for a unit root in time series regression. Biometrika 75: 335-346.

87. Rachev S, Mittnik S, Fabozzi F, Focardi S, Jasic T (2007) Financia Econometrics: from basic to advance modeling techniques, John Wiley and Sons, New York.

88. Lütkepohl H (2005) New Introduction to Multiple Time Series Analysis, Second editions, Springer, Berlin.

89. Liu MH, Shrestha K (2008) Analysis of the long-term relationship between macroeconomic variables and the Chinese stock market using heteroscedastic cointegration. Managerial Financ 34: 744-755.

90. Patra T, Poshakwale S (2008) Long-run and short-run relationship between the main stock indexes: evidence from the Athens stock exchange. Appl Financ Econ 18: $1401-1410$

91. Jansen D (1991) The demand for money in the United States: evidence from cointegration tests. J Money, Credit Bank 23: 155-168.

92. Kirchler M, Huber J (2007) Fat tails and volatility clustering in experimental asset markets. J Econ Dynam Contr 31: 1844-1874.

93. Norma AHP, Robins R (2003) The relationship between Mexican stock marke returns and real, monetary and economic variables. J Econ Dynam Control 13: 251-264.

94. Ekpenyong DB, Obieke IIK (1994) Functional relationship between macroeconomic aggregates and stock prices in the Nigerian economy: A statistical test. J Financ Manage Anal 4: 32-38

95. Abdullah DA, Hayworth SC (1993) Macroeconomatrics of stock prices fluctuations. Quart J Bus Econ 32: 49-63.

96. Adler M, Dumas B (1984) Exposure to currency risk: definition and measurement. Financ Manage 13: 41-49.

97. Aggarwal R (1981) Exchange rate and stock prices. A study of US capital markets under floating exchange rates. Bus Econ Rev 12: 7-12.

98. Ali I, Rehman KU, Yilmaz AK, Khan MA, Afzal H (2010) Causal relationship between macroeconomic indicators and stock exchange prices in Pakistan. Afr J Bus Manage 4: 312-319.

99. Antoniou A, Ergul N, Holmes P (1997) Market efficiency, thin trading and nonlinear behaviour: evidence from an emerging market. Eur Financ Manage 3: $175-190$.

100. Asteriou D, Hall SG (2007) Applied Econometrics: A Modern Approach Using Eviews and Microfit, Revised Edition, Palgrave Macmillan, New York.

101. Baillie RT, DeGennaro RP (1990) Stock return and volatility. J Financ Quan Anal 25: 203-214.

102. Bekaert G, Wu G (2000) Asymmetric volatility and risk in equity markets. Rev Financ Stud 13: 1-42.

103. Bollerslev T (1986) Generalized autoregressive conditional heteroskedasticity. J Econometrics 31: 307-327.
104. Central Bank of Sri Lanka 2015, Statistic, viewed 10 August 2014,

105. Colombo Stock Exchange (2014) Driving change Colombo stock exchange annual report 2014.

106. Colombo Stock Exchange 2016, Data Library, CD, publications of the CSE Sri Lanka.

107. Chakraborty A, Gupta A (2017) Macroeconomic Factors and Indian Stock Market: A Critical Reexamination of APT Model. IPE J Manage 7: 35-41.

108. Cheng AWW, Yip IWH (2017) China's Macroeconomic Fundamentals on Stock Market Volatility: Evidence from Shanghai and Hong Kong. Rev Pac Basin Financ Markets 20: 50-107.

109. Chou RY (1988) Volatility persistence and stock valuations: some empirical evidence using GARCH. J Appl Econometrics 3: 279-294.

110. Dhakal D, Kandil M, Sharma SC (1993) Causality between the money supply and share prices: A VAR investigation. Quart J Bus Econ 32: 52-74.

111. Erdem C, Arslan CK, Erdem MS (2005) Effects of macroeconomic variables on Istanbul stock exchange indexes. Appl Financ Econ 15: 987-994.

112. Engle RF (1982) Autoregressive conditional heteroskedasticity with estimates of the variance of UK inflation. Econometrica 50: 987-1007.

113. Engle RF, Victor K (1991) Measuring and testing the impact of news on volatility. J Financ.

114. EViews User's Guide I and II (Version 6).

115. Hanousek J, Filer RK (2000) The relationship between economic factors and equity markets in Central Europe. Econ Transition 8: 623-638.

116. Islam A, Khaled M (2005) Tests of weak form efficiency of the Dhaka stock exchange. J Bus Financ Account 32: 1613-1624.

117. Kenneth AT (2013) Relationship between volatility and expected returns in two emerging markets. Bus Econ J 84: 1-7.

118. Mensi W, Hammoudeh S, Yoon S, Balcilar M (2016) Impact of macroeconomic factors and country risk ratings on GCC stock markets: evidence from a dynamic panel threshold model with regime switching. J Appl Econ 49: 12551272.

119. McQueen G, Roley V (1993) Stock prices, news and business conditions. Rev Financ Stud 6: 683-707.

120. Malik F, Hammoudeh S (2007) Shock and volatility transmission in the oil, US and Gulf equity markets. Int Rev Econ Financ 16: 357-368.

121. Rachev ST, Stoyan VS, Fabozzi FJ (2008) Advanced stochastic models risk assessment, and portfolio optimization: The ideal risk, uncertainty, and performance measures, John Wiley and Sons, New York.

122. Sharpe WF (1964) Capital asset prices: a theory of market equilibrium under conditions of risk. J Financ 19: 425-442.

123. Solnik B (1987) Using financial prices to test exchange rate models: A note Journal of Finance 42: 141-149.

124.Timmermann A, Granger CWJ (2004) Efficient market hypothesis and forecasting. Int J Forecast 20: 15-27.

125. Titman S, Warga A (1989) Stock returns as predictors of interest rates and inflation. J Financ Quant Anal 24: 47-58.

126.Zolotoy L, Frederickson JR, Lyon JD (2017) Aggregate earnings and stock market returns: The good, the bad, and the state-dependent. J Bank Financ 77: 157-175. 